J. Asiat. Soc. Bangladesh, Sci. 46(1): 81-89, June 2020

\title{
EVALUATION OF FUNGICIDES AND PLANT EXTRACTS AGAINST PATHOGENIC FUNGI ASSOCIATED WITH BASELLA SPP.
}

\author{
NUSRAT JAHAN SHOVA, SAROWAR HOSEN AND M.A. BASHAR* \\ Department of Botany, University of Dhaka, Dhaka-1000, Bangladesh
}

\begin{abstract}
Five fungicides viz., CM 75, Dithane M 45, Knowin 50 WP, Nativo 75 WG and Rovral 50 WP were evaluated against Colletotrichum lindemuthianum, Drechslera sacchari and Fusarium semitectum following poisoned food technique. Out of five fungicides complete inhibition of radial growth of $C$. lindemuthianum was observed in Nativo 75 WG at $100 \mathrm{ppm}$. On the other hand, the complete inhibition of the growth of $D$. sacchari was observed with Rovral $50 \mathrm{WP}$ at $400 \mathrm{ppm}$, whereas Nativo $50 \mathrm{WP}$ showed complete growth inhibition at $500 \mathrm{ppm}$. CM $75 \mathrm{WP}$, Knowin $50 \mathrm{WP}$ and Nativo 75 WG showed complete growth inhibition of $F$. semitectum at $100 \mathrm{ppm}$. Five different plant leaf extracts viz., Azadirachta indica A. Juss., Heliotropium indicum L., Lippia alba L., Michelia champaca L. and Thuja occidentalis L. were tested against the test pathogens. Of the five plant leaf extracts, Lippia alba showed the highest growth inhibition in C. lindemuthianum, D. sacchari and F. semitectum at $20 \%$ concentration.
\end{abstract}

Key words: Fungicides, Plant extracts, Pathogenic fungi, Basella spp.

\section{Introduction}

Basella is a popular tropical leafy-green vegetable, belongs to Basellaceae (Sushila et al. 2010) and has two chief cultivars namely, Basella alba and B. rubra (Cook 2010). A vast amount of yield is lost in terms of quantity and quality due to various constraints (Hasan et al. 2016). Proper management strategy of leaf spot of Basella spp. is very essential for the economical point of view. Various workers in different countries of the world evaluated the efficacy of various fungicides against Colletotrichum spp., Macrophomina phaseolina, Fusarium spp., C. gloeosporioides and Alternaria spp. under laboratory and field conditions (Hossain and Bashar 2011, Ahmed et al. 2014, Chowdhury et al. 2015, Mamun et al. 2016, Hosen et al. 2016, Islam et al. 2017). Some researchers have used different chemical fungicides to control leaf spot disease of Basella and have achieved various degree of success (Khan and Smith 2005). The residue of chemical fungicides poses potential health hazard (Alemu et al. 2014). The alternate approaches like using plant extracts were found to be effective against the pathogen (Uddin et al. 2013, Maketon et al. 2008). Plant extracts are considered as new rays of hope because they are

*Corresponding author: botanybashar@yahoo.com 
eco-friendly and can be used as an alternative measure to control plant diseases. Recently, some researchers have indicated the possibility of their exploitation as natural fungitoxicants for controlling plant diseases (Sharmin and Shamsi 2013, Mamun et al. 2016, Hosen et al. 2016, Islam et al. 2017). The aim of this study was to evaluate the common and easily available fungicides as well as selected plants to determine minimum inhibitory concentration (MIC) values of various levels to find out the most suitable one to reduce yield and post-harvest losses caused by leaf spot of Basella spp.

\section{Materials and Methods}

The samples were collected from three markets of Dhaka city viz., Karwan Bazar, Anando Bazar and Polashi Bazar during April to November, 2017. Fungi associated with the leaf spot of Basella spp. were isolated following Tissue planting method (CAB 1968). Pathogenicity test has been done according 'detached leaf assay' followed by Azad and Shamsi (2011) with slight modification. Five fungicides with different active ingredients viz., CM 75 WP (Mancozeb 63\% + carbendazim 12\%), dithane M 45(80\% Mancozeb), Knowin 50 WP [50\% carbendazim (methyl benimidazol-2-ylcarbamate)], Nativo 75 WG (500 g tebuconazol, $250 \mathrm{~g}$ trifloxy-strobin) and Rovral $50 \mathrm{WP}$ (Iprodione) were collected from the Siddique Bazar, Fulbariya, Gulistan, Dhaka. These fungicides were evaluated for their in vitro efficacy at different concentrations (100, 200, 300, 400 and $500 \mathrm{ppm}$ ) against pathogenic fungi associated with Basella spp.

A total of five different plant leaf extracts viz., Azadirachta indica A. Juss., Heliotropium indicum L., Lippia alba L., Michelia champaca L. and Thuja occidentalis L. were screened against the selected test pathogens. Leaves of Lippia alba L. were collected from Bhairab, Narsingdi and the rest of the plant's leaves were collected from the Botanical garden of Curzon Hall campus, University of Dhaka. In vitro efficacy of selected plant leaf extracts at 5, 10,15 and 20\% concentrations were evaluated against the test pathogens following the method described by Helal and Shamsi (2018). The desired leaves of each plant were thoroughly washed in tap water, air dried and were prepared by crushing to known weight of fresh materials with distilled water in ratio of 1:1 (w/v). The pulverized mass of a plant part was squeezed through four-folds of fine cloth and the extracts were centrifuged at $3000 \mathrm{rpm}$ for $20 \mathrm{~min}$ to remove particles. The supernatants were filtered through Whatman filter paper No. 1 and the filtrate was collected in $250 \mathrm{ml}$ Erlenmeyer flask. The requisite amount of the filtrate of each plant extract was mixed with PDA medium to get 5, 10, 15 and $20 \%$ concentrations. In control, required amount of water was used instead of plant extract. All the Petri plates were incubated at $25 \pm 2^{\circ} \mathrm{C}$. 
The radial growth of the test pathogen colonies was measured after 7 days. The per cent growth inhibition of each test pathogen was calculated using the following formula:

$$
\mathrm{I}=\frac{\mathrm{C}-\mathrm{T}}{\mathrm{C}} \times 100
$$

where, $\mathrm{I}=$ Per cent growth inhibition, $\mathrm{C}=$ Growth in control, $\mathrm{T}=$ Growth in treatment.

The data were collected as per cent inhibition of the radial growth of the test pathogens in $\mathrm{mm}$ and evaluated by ANOVA by using STAR statistical program and means were compared using DMRT.

\section{Results and Discussion}

Ten fungi viz., Alternaria alternata, Aspergillus flavus, A. fumigatus, A. niger, Colletotrichum dematium, C. lindemuthianum, Curvularia lunata, Drechslera sacchari, Fusarium semitectum and Penicillium sp. were isolated from the leaf spot of Basella spp. Among the isolated fungi, C. lindemuthianum, D. sacchari and F. semitectum were selected as test pathogens owing to their pathogenic potentiality.

Amongst the five fungicides, complete inhibition of the radial growth of Colletotrichum lindemuthianum was observed with Nativo $75 \mathrm{WG}$ at $100 \mathrm{ppm}$ concentration. Out of rest four fungicides, the highest growth inhibition of $C$. lindemuthianum was observed with CM 75 WP (68.84\%) which was followed by Knowin 50 WP (63.08\%), Rovral 50 WP (60.25\%) and Dithane M 45 (59.10\%) at 500 ppm concentration (Table 1).

Ann et al. (2017) reported the application of Nativo which significantly suppressed the development of leaf anthracnose and black berries disease caused by Colletotrichum gloeosporioides. Rajesha et al. (2010) reported that mancozeb completely inhibited the radial mycelial growth of $C$. lindemuthianum at $400 \mathrm{ppm}$ concentration. Suresh and Ekbote (2005) also observed carbendazim as most effective in inhibiting the growth of $C$. lindemuthianum.

On the other hand, the complete inhibition of growth of D. sacchari was observed with Rovral $50 \mathrm{WP}$ at $400 \mathrm{ppm}$ concentration, whereas Nativo $75 \mathrm{WG}$ showed complete growth inhibition at $500 \mathrm{ppm}$ concentration and the highest growth inhibition $(84.41 \%)$ at 400 ppm concentration (Table 2). Jadon and Shah (2012) observed that CM 75 WP at 500 ppm concentration completely inhibited the mycelial growth of Drechslera bicolor. Wahid et al. (1992) found thiophanate methyl as the best fungicide followed by captan against Drechslera sacchari. CM 75 WP, Knowin 50 WP and Nativo 75 WP showed 
complete growth inhibition of $F$. semitectum at all the treated concentrations whereas Rovral 50 WP

Table 1. Inhibition of radial growth (\%) of Colletotrichum lindemuthianum at different concentrations of fungicides.

\begin{tabular}{llllll}
\hline \multirow{2}{*}{$\begin{array}{l}\text { Name of } \\
\text { fungicides }\end{array}$} & \multicolumn{4}{c}{$\%$ inhibition of radial growth at different concentrations (ppm) } \\
\cline { 2 - 6 } & 100 & 200 & 300 & 400 & 500 \\
\hline CM 75 WP & $50.14^{\mathrm{b}}$ & $56.58^{\mathrm{b}}$ & $59.05^{\mathrm{b}}$ & $61.42^{\mathrm{b}}$ & $68.84^{\mathrm{b}}$ \\
Dithane M 45 & $14.18^{\mathrm{c}}$ & $46.73^{\mathrm{c}}$ & $49.17^{\mathrm{c}}$ & $52.01^{\mathrm{cd}}$ & $59.10^{\mathrm{d}}$ \\
Knowin 50 WP & $57.05^{\mathrm{b}}$ & $58.05^{\mathrm{b}}$ & $59.06^{\mathrm{b}}$ & $60.73^{\mathrm{bc}}$ & $63.08^{\mathrm{c}}$ \\
Nativo 75 WG & $100^{\mathrm{a}}$ & $100^{\mathrm{a}}$ & $100^{\mathrm{a}}$ & $100^{\mathrm{a}}$ & $100^{\mathrm{a}}$ \\
Rovral 50 WP & $15.40^{\mathrm{c}}$ & $21.38^{\mathrm{d}}$ & $36.78^{\mathrm{d}}$ & $50.57^{\mathrm{d}}$ & $60.23^{\mathrm{d}}$ \\
CV $(\%)$ & 8.62 & 3.70 & 5.82 & 5.50 & 2.60 \\
\hline
\end{tabular}

Means followed by the same letter within a column did not differ significantly at $5 \%$ level by DMRT.

Table 2. Inhibition of radial growth (\%) of Drechslera sacchari at different concentrations of fungicides.

\begin{tabular}{llllll}
\hline \multirow{2}{*}{$\begin{array}{l}\text { Name of } \\
\text { fungicides }\end{array}$} & \multicolumn{5}{c}{ \% inhibition of radial growth at different concentrations $(\mathrm{ppm})$} \\
\cline { 2 - 6 } & 100 & 200 & 300 & 400 & 500 \\
\hline CM 75 WP & $36.59^{\mathrm{b}}$ & $52.51^{\mathrm{b}}$ & $61.45^{\mathrm{b}}$ & $64.24^{\mathrm{b}}$ & $65.64^{\mathrm{c}}$ \\
Dithane M 45 & $22.11^{\mathrm{c}}$ & $57.19^{\mathrm{b}}$ & $60.35^{\mathrm{b}}$ & $60.70^{\mathrm{b}}$ & $73.68^{\mathrm{b}}$ \\
Knowin 50 WP & $11.08^{\mathrm{d}}$ & $18.18^{\mathrm{c}}$ & $22.72^{\mathrm{c}}$ & $26.14^{\mathrm{c}}$ & $38.35^{\mathrm{d}}$ \\
Nativo 75 WG & $74.03^{\mathrm{a}}$ & $79.74^{\mathrm{a}}$ & $80.00^{\mathrm{a}}$ & $84.41^{\mathrm{a}}$ & $100^{\mathrm{a}}$ \\
Rovral 50 WP & $71.80^{\mathrm{a}}$ & $72.58^{\mathrm{a}}$ & $84.33^{\mathrm{a}}$ & $100^{\mathrm{a}}$ & $100^{\mathrm{a}}$ \\
CV (\%) & 6.56 & 7.03 & 4.41 & 3.11 & 3.57 \\
\hline
\end{tabular}

Means followed by the same letter within a column did not differ significantly at $5 \%$ level by DMRT.

showed complete growth inhibition at 500 ppm concentration. Rovral 50 WP showed 62.46 and $75.44 \%$ growth inhibition at 300 and $400 \mathrm{ppm}$ concentrations, respectively. Dithane M 45 showed 16.91, 20.69, 53.93, 57.72 and 69.39\% growth inhibition at 100, 200, 300, 400 and 500 ppm concentrations, respectively (Table 3). It is also noticed from the results that the per cent growth inhibition of the test pathogens gradually increased with the increase of concentration of the fungicides in culture media. 
Hoque et al. (2016) reported that radial colony diameter of $F$. semitectum was significantly reduced over control due to amendment of PDA with Bavistin (carbendazin). The aforesaid fungicide showed $100 \%$ radial growth inhibition of $F$. semitectum. Pramesh et al. (2016) also found effective against blast and sheath blight diseases of rice by using Nativo 75 WG.

In vitro efficacy of various fungicides against the test pathogens indicated that CM 75 WP, Nativo 75 WG and Rovral 50 WP showed promising results as compared to others (Tables 1-3). The same fungicides also showed different effects on tested fungi in the present investigation. This variation might be due to selection of different strains of test pathogens.

Table 3. Inhibition of radial growth (\%) of Fusarium semitectum at different concentrations of fungicides.

\begin{tabular}{llllll}
\hline \multirow{2}{*}{$\begin{array}{l}\text { Name of } \\
\text { fungicides }\end{array}$} & \multicolumn{4}{c}{$\%$ inhibition of radial growth at different concentrations (ppm) } \\
\cline { 2 - 6 } & 100 & 200 & 300 & 400 & 500 \\
\hline CM 75 WP & $100^{\mathrm{a}}$ & $100^{\mathrm{a}}$ & $100^{\mathrm{a}}$ & $100^{\mathrm{a}}$ & $100^{\mathrm{a}}$ \\
Dithane M 45 & $16.91^{\mathrm{b}}$ & $20.69^{\mathrm{c}}$ & $53.93^{\mathrm{b}}$ & $57.72^{\mathrm{c}}$ & $69.39^{\mathrm{b}}$ \\
Knowin 50 WP & $100^{\mathrm{a}}$ & $100^{\mathrm{a}}$ & $100^{\mathrm{a}}$ & $100^{\mathrm{a}}$ & $100^{\mathrm{a}}$ \\
Nativo 75 WG & $100^{\mathrm{a}}$ & $100^{\mathrm{a}}$ & $100^{\mathrm{a}}$ & $100^{\mathrm{a}}$ & $100^{\mathrm{a}}$ \\
Rovral 50 WP & $21.05^{\mathrm{b}}$ & $28.77^{\mathrm{b}}$ & $62.46^{\mathrm{b}}$ & $75.44^{\mathrm{b}}$ & $100^{\mathrm{a}}$ \\
CV (\%) & 7.00 & 6.71 & 3.03 & 2.80 & 0.69 \\
\hline
\end{tabular}

Means followed by the same letter within a column did not differ significantly at $5 \%$ level by DMRT.

Results of leaf extracts on the radial growth of Colletotrichum lindemuthianum, Drechslera sacchari and Fusarium semitectum are presented in Tables 4-6. All the plant extracts showed distinct degree of growth inhibition of the test pathogens at 5, 10, 15 and $20 \%$ concentrations. Among the five plant extracts, Lippia alba showed complete growth inhibition of $C$. lindemuthianum at $20 \%$ concentration which was followed by Azadirachta indica (47.59\%), Thuja occidentalis (46.05\%), Heliotropium indicum (24.67\%) and Michelia champaca $(23.89 \%)$ (Table 4). The inhibition of the pathogen increases with the increase of the concentration of the plant leaf extracts in culture medium. Choudhary et al. (2017) reported that leaf extract of A. indica significantly reduced $(78.83 \%)$ the mycelial growth of $C$. lindemuthianum at $10 \mathrm{ppm}$. 
Out of five plant extracts, Lippia alba showed complete radial growth inhibition of $D$. sacchari at $20 \%$ concentration which was followed by A. indica (50.09\%), Thuja occidentalis (50\%), Heliotropium indicum (40.49\%) and Michelia champaca (28.19\%) (Table 5). Miah et al. (2017) reported that BARI Gom-26 variety showed the lowest fungal infection (6\%) owing to A. indica and Thuja occidentalis plant extract followed by Citrus limon (8\%), Allium sativum (10\%) and Datura metel (10\%). Jadon and Shah (2012) found $A$. indica as the best mycelial growth inhibitor among the perennials against the Drechslera bicolor.

Table 4. Effect of plant leaf extracts on the radial growth of Colletotrichum lindemuthianum at different concentrations.

\begin{tabular}{lcccc}
\hline \multirow{2}{*}{$\begin{array}{l}\text { Name of } \\
\text { plants }\end{array}$} & \multicolumn{4}{c}{ Per cent inhibition of radial growth at different concentrations (\%) } \\
\cline { 2 - 5 } & 5 & 10 & 15 & 20 \\
\hline Azadirachta indica & $26.62^{\mathrm{a}}$ & $31.87^{\mathrm{b}}$ & $37.12^{\mathrm{b}}$ & $47.59^{\mathrm{b}}$ \\
Heliotropium indicum & $14.80^{\mathrm{b}}$ & $17.92^{\mathrm{c}}$ & $19.48^{\mathrm{c}}$ & $24.67^{\mathrm{c}}$ \\
Lippia alba & $39.68^{\mathrm{b}}$ & $41.90^{\mathrm{ab}}$ & $45.39^{\mathrm{a}}$ & $100^{\mathrm{a}}$ \\
Michelia champaca & $12.46^{\mathrm{b}}$ & $14.80^{\mathrm{c}}$ & $19.48^{\mathrm{c}}$ & $23.89^{\mathrm{c}}$ \\
Thuja occidentalis & $27.91^{\mathrm{a}}$ & $40.69^{\mathrm{a}}$ & $44.65^{\mathrm{a}}$ & $46.05^{\mathrm{b}}$ \\
CV $(\%)$ & 15.99 & 12.89 & 9.85 & 5.81 \\
\hline
\end{tabular}

Means followed by the same letter within a column did not differ significantly at $5 \%$ level by DMRT.

Table 5. Effect of plant leaf extracts on the radial growth of Drechslera sacchari at different concentrations.

\begin{tabular}{lllll}
\hline \multirow{2}{*}{$\begin{array}{l}\text { Name of } \\
\text { plants }\end{array}$} & \multicolumn{4}{c}{ Per cent inhibition of radial growth at different concentrations (\%) } \\
\cline { 2 - 5 } & 5 & 10 & 15 & 20 \\
\hline Azadirachta indica & $30.34^{\mathrm{b}}$ & $36.80^{\mathrm{b}}$ & $38.34^{\mathrm{b}}$ & $50.09^{\mathrm{b}}$ \\
Heliotropium indicum & $28.05^{\mathrm{b}}$ & $34.84^{\mathrm{b}}$ & $38.25^{\mathrm{c}}$ & $40.49^{\mathrm{d}}$ \\
Lippia alba & $47.07^{\mathrm{a}}$ & $54.39^{\mathrm{a}}$ & $62.23^{\mathrm{a}}$ & $100^{\mathrm{a}}$ \\
Michelia champaca & $16.86^{\mathrm{c}}$ & $19.27^{\mathrm{c}}$ & $23.61^{\mathrm{d}}$ & $28.19^{\mathrm{e}}$ \\
Thuja occidentalis & $27.78^{\mathrm{b}}$ & $39.33^{\mathrm{b}}$ & $45.11^{\mathrm{b}}$ & $50.00^{\mathrm{c}}$ \\
CV (\%) & 9.13 & 9.48 & 5.28 & 3.32 \\
\hline
\end{tabular}

Means followed by the same letter within a column did not differ significantly at $5 \%$ level by DMRT.

The highest inhibition of radial growth of $F$. semitectum was observed with Lippia alba (100\%) at $20 \%$ concentration which was followed by A. indica $(46.47 \%)$, T. occidentalis (41.46\%), M. champaca (20.73\%) and H. indicum (17.97\%) (Table 6). Sinha and Varma 
(2017) reported that the ethanolic, methanolic and aqueous extracts of M. champaca L. exhibited antioxidant and free radical activity.

Out of the five plant extracts Lippia alba, Azadirachta indica and Thuja occidentalis showed maximum radial growth inhibition of $C$. lindemuthianum, D. sacchari and $F$. semitectum at $20 \%$ concentration. But Heliotropium indicum and Michelia champaca showed minimum growth inhibition of the test pathogens.

Table 6. Effect of plant leaf extracts on the radial growth of Fusarium semitectum at different concentrations.

\begin{tabular}{lllll}
\hline \multirow{2}{*}{$\begin{array}{l}\text { Name of } \\
\text { plants }\end{array}$} & \multicolumn{4}{c}{ Per cent inhibition of radial growth at different concentrations (\%) } \\
\cline { 2 - 5 } & 5 & 10 & 15 & 20 \\
\hline Azadirachta indica. & $29.05^{\mathrm{a}}$ & $38.59^{\mathrm{a}}$ & $40.87^{\mathrm{a}}$ & $46.47^{\mathrm{b}}$ \\
Heliotropium indicum & $7.83^{\mathrm{d}}$ & $11.59^{\mathrm{d}}$ & $14.49^{\mathrm{d}}$ & $17.97^{\mathrm{d}}$ \\
Lippia alba & $15.20^{\mathrm{c}}$ & $39.18^{\mathrm{a}}$ & $44.44^{\mathrm{a}}$ & $100^{\mathrm{a}}$ \\
Michelia champaca & $10.36^{\mathrm{d}}$ & $14.14^{\mathrm{c}}$ & $18.29^{\mathrm{c}}$ & $20.73^{\mathrm{d}}$ \\
Thuja occidentalis & $26.83^{\mathrm{b}}$ & $31.71^{\mathrm{b}}$ & $37.80^{\mathrm{b}}$ & $41.46^{\mathrm{c}}$ \\
CV $(\%)$ & 14.12 & 6.93 & 6.41 & 5.16 \\
\hline
\end{tabular}

Means followed by the same letter within a column did not differ significantly at $5 \%$ level by DMRT.

Basella spp. is an important plant for its nutritional, medicinal point of view. So, the production of the vegetables by controlling various diseases it is necessary to identify the most prevalent pathogen causing leaf spot and to reduce the yield as well as post-harvest loss of the vegetables. The results of this investigation identified Nativo and Rovral as the best inhibiting fungicides against leaf spot of Basellla spp. Leaf extracts of Lippia alba and Azadirachta indica identified as an effective botanical against for further testing against pre-harvest diseases of Basella spp.

\section{References}

Ahmed, M.J., K.S. Hossain and M.A. Bashar. 2014. Anthracnose of betel vine and its in vitro management. Dhaka Univ. J. Biol. Sci. 23(2): 127-133.

Alemu, K., A. Ayalew and K. Woldetsadik. 2014. Effect of aqueous extracts of some medicinal plants in controlling anthracnose disease and improving postharvest quality of mango fruit. Persian Gulf Crop Prot. 3(3): 84-92.

Ann, Y.C., J. Zehnder and M. Augustine. 2017. Efficacy of tebuconazole and trifloxystrobin against Colletotrichum gloeosporioides infestation in black pepper (Piper nigrum L.). Am. J. Res. Commun. 5(1): 98-128.

Azad, R. and S. Shamsi. 2011. Identification and pathogenic potentiality of fungi associated with Houttuynia cordata Thunb. Dhaka Univ. J. Biol. Sci. 20(2): 131-138. 
CAB (Commonwealth Agricultural Bureau), 1968. Plant Pathologist's Pocket Book. $1^{\text {stedn. The }}$ Commonwealth Mycological Institute, England. pp. 267.

Choudhary, R.S., S. Simon and S.R. Bana. 2017. Efficacy of plant extracts against anthracnose (C. lindemuthianum) of green gram (Vigna radiata L.). Int. J. Chem. Stud. 5(4): 769 -772.

Chowdhury, P., M.A. Bashar and S. Shamsi. 2015. In vitro evaluation of fungicides and plant extracts against pathogenic fungi of two rice varieties. Bangladesh J. Bot. 44(2): 251-259.

Cook, A. 2010. Linnaeus and Chinese plants: A test of the linguistic imperialism thesis. Notes Rec. R. Soc. 64: 121-138.

Hasan, M.A., N.B. Islam, S. Naznin, M.M. Islam and Kishowar-E-Mustarin. 2016. Management of Cercospora leaf spot of Indian Spinach (Basella alba L.) with BAU Bio-fungicide and a plant growth promoting hormone. Univers. J. Plant Sci. 4(4): 43-49.

Helal, R.B. and S. Shamim. 2018. In vitro screening of fungicides and plant extracts against pathogenic fungi associated with infected fruits of Carica papaya L. J. Bangladesh Acad. Sci. 42(2): 121-128.

Hoque, M.Z., A.M. Akanda, M.I.H. Miah, M.K.A. Bhuiyan, M.G. Miah and F. Begum. 2016. In vitro screening of fungicides and tannins against fungal pathogens of jujube fruits. Progress. Agric. 27(2): 154-161.

Hosen, S., S. Shamsi and M.A. Bashar. 2016. In vitro efficacy of fungicides and plant extracts on the growth of Colletotrichum gloeosporioides (Penz.) Penz. \& Sacc. and Sclerotium rolfsii Sacc. the causal organisms of anthracnose and soft rot of jute. Dhaka Univ. J. Biol. Sci. 25(2): 195-199.

Hossain, K.S. and M.A. Bashar. 2011. In vitro effect of plant extracts, fungicides and antibiotics on the fungal isolates associated with damping-off disease of crucifers. J. Agrofor. Environ. 5(2): 17-20.

Islam, M.A., S. Shamsi, S. Hosen and M.A. Bashar. 2017. In vitro effects of plant extracts and fungicides to control wilt of brinjal (Solanum melongena L.). Dhaka Univ. J. Biol. Sci. 26(1): 39-44.

Jadon, K.S. and R. Shah. 2012. Antifungal activity of different plant extracts against Drechslera bicolor causing leaf blight of bell pepper. Arch. Phytopathol. Plant Prot. 45: 1417-1428.

Khan, M.F. and L.J. Smith. 2005. Evaluating fungicides for controlling Cercospora leaf spot on sugarbeet. Crop Prot. 24(1): 79-86.

Maketon, M., J. Apisitsantikul and C. Siriraweekul. 2008. Greenhouse evaluation of Bacillus subtilis AP-01 and Trichoderma harzianum AP-001 in controlling tobacco diseases. Brazil. J. Microbiol. 39(2): 296-300.

Mamun, M.A., S. Shamsi and M.A. Bashar. 2016. In vitro evaluation of fungicides and plant extracts against pathogenic fungi of jute seeds. Biores. Comm. 2(1): 189-192.

Miah, A., S. Shamsi, S. Hosen and M.S. Morshed. 2017. In vitro efficacy of plant extracts on seed germination and fungal infection of six varieties of wheat (Triticum aestivum L.) Biores. Comm. 3(2): 415-421.

Pramesh, D., Maruti, K.M. Muniraju, K. Mallikarjun, G.S. Guruprasad, K. Mahantashivayogayya, B.G.M. Reddy, S.B. Gowdar and B.S. Chethana. 2016. Bio-efficacy of a combination fungicide against blast and sheath blight diseases of paddy. J. Exp. Agric. Int.14(4): 1-8.

Rajesha, G., S.G. Mantur, M.R. Shankar, M.B. Boranayaka and T.V. Shadakshari. 2010. In vitro evaluation of fungicides and biocontrol agents against $C$. lindemuthianum causing anthracnose of dolichos bean. Int. J. Plant Prot. 3(1): 114-116.

Sushila, R., A. Deepti, R. Permender, T. Madhari and R. Dharmender. 2010. Cytotoxic and antibacterial activity of Basella alba whole plant: A relatively unexplored plant. Pharmacology Online 3: 651-658. 
Sharmin, S. and S. Shamsi. 2013. In vitro control of five pathogenic fungi isolated from groundnut (Arachis hypogaea L.). J. Asiat. Soc. Bangladesh, Sci. 39(1): 27-33.

Sinha, R. and R. Varma. 2017. Antioxidant activity in leaf extracts of Michelia champaca L. J. Adv. Pharm. Educ. Res. 7(2): 86-88.

Suresh, and D. Ekbote. 2005. Management of chilli fruit rot caused by C. capsici. J. Mycol. Pl. Pathol. 35(1): 183.

Uddin, M.N., M.A. Bakr, M.R. Islam, M.I. Hossain and A. Hossain. 2013. Bioefficacy of plant extracts to control Cercospora leaf spot of mungbean (Vigna radiata). Int. J. Agric. Res, Innov. Technol. 3(1): 60-65.

Wahid, A., A. Saleem, S. Ali and T. Masoud. 1992. Fungicidal control of seedling blight of sugarcane caused by D. sacchari. Pak J. Phytopathol. 2: 14-21.

(Revised copy received on 12.06.2020) 